\title{
Preserving Wilderness at an Emerging Tourist Destination
}

\author{
Anna Dóra Sæbórsdóttir ${ }^{1}$ \\ ${ }^{1}$ Faculty of Life and Environmental Sciences, University of Iceland, Reykjavík, Iceland \\ Correspondence: Anna Dóra Sæpórsdóttir, Faculty of Life and Environmental Sciences, University of Iceland, \\ Reykjavík, Iceland. Tel: 354-525-4287. E-mail: annadora@hi.is
}

Received: April 23, $2014 \quad$ Accepted: May 13, $2014 \quad$ Online Published: August 29, 2014
doi:10.5539/jms.v4n3p65

\begin{abstract}
Iceland is an emerging tourist destination with a huge growth in tourist arrivals where wilderness as an important part of the attraction.But visitors travel into wilderness to experience naturalness and solitude so when wilderness becomes a popular tourist destination these qualities are difficult to preserve. This research builds on questionnaire surveys gathered among 3941 travelers at nine areas in the Highlands of Iceland where the aim was to explore to what extent travelers experience wilderness in the Highlands of Iceland and whether they experience that the carrying capacity of the destinations in the Highlands has been reached. It furthermore discusses the possible use limits of wilderness as an arena for tourism. The results show that despite substantial human influence travelers experience wilderness. Most travelers consider the number of tourists appropriate, although some warning signs are emerging as $40 \%$ of tourists consider that there are too many tourists in one of the areas. Visitors prefer simplicity and wish to keep the places as natural as possible, with one exception at the most visited destination. There the attitudes of visitors are more anthropocentric, favoring more humanized landscape and service. Using wilderness as a tourism product is a very challenging task in an emerging destination where tourism growth is as fast as it is in Iceland.
\end{abstract}

Keywords: wilderness, tourism, Iceland, perception, impact, purist scale

\section{Introduction}

Iceland is an emerging tourist destination in the North Atlantic with nature and wilderness as the main attraction. In the last three decades Iceland has experienced a dramatic growth in international tourist arrivals with approximately $8 \%$ average annual growth, from 72600 arrivals in 1982 to 781000 in 2013 . The annual growth has been particularly strong in the last three years, or about 17\% (Icelandic Tourist Board, 2014). This is high, especially if compared with 5\% growth in tourist arrivals in Europe and worldwide in 2013 (UNWTO, 2014). Accordingly the share of tourism in total export in Iceland has increased fast and tourism is now the largest export sector with 26,8\% of the export share in 2013 (Statistics Iceland, 2014).

Wilderness environment characterizes approximately $33 \%$ of the total area of Iceland (Ólafsdóttir \& Runnstrom, 2011) of which $60 \%$ is located in the Central Highlands, the uninhabited interior of Iceland (National Planning Agency, 2012). The Highlands are very popular among travelers as more than one third of foreign summer tourists visit the area (Icelandic Tourist Board, 2012). This makes the Highlands very important for nature-based and wilderness tourism. The very fast growth of tourism raises concerns regarding the difficulties of preserving the wilderness there, maintaining the qualities of the resource and the experiences of visitors. Recent studies (Sæpórsdóttir, 2013) indicate that in the most frequented destination in the Highlands, Landmannalaugar the carrying capacity of visitors might be reached. For management purposes it is necessary to know and follow these changes as a common resource can only be protected from overuse with management and control (Butler, 2010).

This paper presents the results from questionnaire surveys on wilderness experiences conducted among travelers at nine Highland areas in Iceland. The aim of the surveys is to explore to what extent travelers experience wilderness in the Highlands of Iceland and whether they experience that the carrying capacity of the destinations in the Highlands has been reached. It furthermore discusses the possible use limits of wilderness as an arena for tourism. 


\section{Wilderness as a Tourist Destination}

Wilderness and unspoilt nature have become major attractions for tourists (Hall \& Saarinen, 2010). They are supposed to offer opportunities to experience naturalness, primitiveness and solitude (Hendee, Stankey, \& Lucas, 1990; Higham, 1998; Roggenbuck, Williams, \& Watson, 1993). However, as wilderness becomes known as a tourist destination maintaining these conditions becomes increasingly difficult (e.g., Lawson \& Manning, 2001; Manning, Valliere, \& Wang, 1999; Nash, 2001; Sæpórsdóttir, 2013). As a response to increased visitation more facilities tend to be built and thereby the naturalness declines.

Satisfaction in a wilderness destination is furthermore reduced by the perception of increased crowding (e.g., Lawson \& Manning, 2001; Manning, et al., 1999; Patterson \& Hammitt, 1990; D. R. Williams, Roggenbuck, \& Bange, 1991). Wilderness areas are particularly sensitive towards increasing number of visitors and the resulting degradation (Higham, 1998). Therefore, if a wilderness area is to provide satisfaction only a limited number of visitors can visit it simultaneously. The connection between growing numbers of tourists and the decline of destinations has been pointed out by many (Butler, 1980, 1999, 2010; Hunter \& Green, 1995; Saarinen, 2013a, 2013b; P. W. Williams \& Gill, 2004).

For assessing the impacts of tourism the ideas of limits to growth, or tourism carrying capacity (TCC), have been used in wilderness and tourist destination management, both from the point of view of the impact of visitors on the environment, the physical carrying capacity (e.g., Hammitt \& Cole, 1987; Travel, 2012), and from the point of view of the impact people have on other people, that is the psychological carrying capacity (e.g., Shelby \& Heberlein, 1986; Simón, Narangajavana, \& Marqués, 2004). TCC is at the heart of Butler's (1980) TALC model of tourism area life-cycle, which is the most cited and most frequently used model in tourism literature (Butler, 2009). It describes the development tourist destinations go through as the various capacity levels (e.g., environmental, social and economic) are reached. As the destination develops the type of tourist changes, from adventure seekers in the involvement stage, to mass tourism in the stagnation stage. As the number of visitors increases and the developments exceed their level of suitability the attraction of the area will be reduced and visitation will decline. Butler (2004a) points out that overuse and overdevelopment of the destination is inevitable if no action is taken. According to Butler (1980, 2004a, 2010), a common resource can only be protected from overuse with regulation and control. In order to encourage the long and successful life of a destination, planning and appropriate management are necessary. That includes identifying limits to growth and development in wilderness (Saarinen, 2013a, 2013b). Without these limitations, the destination will surpass its TCC, and become unsustainable. The concept of TCC plays a key role with regard to the sustainable development of tourism (Butler, 1997, 1999; Saarinen, 1998, 2006, 2013b) as tourism development is not sustainable when capacity limits are not respected (Butler, 1997; Saarinen, 2006).

Several frameworks and models have been developed and used in the management of natural areas for tourism and outdoor recreation. One of them is the so-called Purist scale model (Fredman \& Emmelin, 2001; Hendee, Catton Jr., Marlow, \& Brockman, 1968; Stankey, 1973; Sæbórsdóttir, 2010a; Vistad \& Vorkinn, 2012) which helps to find target groups in wilderness and natural areas according to the qualities and settings each location offers. In the model, visitors are divided into groups according to their preferences. At one extreme are strong purists who prefer to travel with primitive facilities in an unspoiled environment, highly appreciate solitude and dislike restrictions on their behavior. At the other end at the scale are urbanists who appreciate a variety of services and facilities, do not respond strongly to environmental disturbances and are not sensitive to the number of travelers.

When determining the appropriate use level for a given destination it is not enough to find what the present visitors consider to be an acceptable setting. As Butler (1997, p. 18) points out:

Adopting an approach which relies on identifying what users regard as acceptable change, and basing usage levels on user norms and expectations can only result in increasing levels of use and development as those users concerned by development and increasing numbers will go elsewhere and will be replaced by those with higher use threshold levels.

Therefore, many destinations would exceed their use level and would not be able to maintain themselves at existing levels of quality and thereby not be sustainable if they would rely solely on the opinion of tourists (Butler, 1997).

Determining the TCC of a given system is a judgemental act and in order to determine the carrying capacity it is necessary to have clear management objectives (Cole, 2004; Lime \& Stankey, 1971; McCool, Clark, \& Stankey, 2007), as well as skilful and firm management (Butler, 1997; Butler, Fennell, \& Boyd, 1992). For that, it is necessary to decide how much ecological decline is acceptable, what kind of tourism the area is intended for and 
what kind of experience it is supposed to offer. The decisions that managers take have to be built on a factual basis and Cole (2004) stresses the role of science in providing the information and facts required.

\section{Wild Iceland}

Nature is the most important attraction in Iceland and the reason for that almost $90 \%$ of all international tourists visit the country (Icelandic Tourist Board, 2013). About 36.3\% of international summer tourists visit the Central Highlands (Icelandic Tourist Board, 2012), an uninhabited area which covers about $40 \%$ of the country (figure 1) (Ministry of the environment \& The National Planning Agency, 1999). The landscape there is diverse, characterized by wide open spaces, with vast lava fields, sandy or stony deserts, large ice caps, geothermal areas and mountains (Thórhallsdóttir, 1997, 2002). According to the official Icelandic definition of wilderness (Icelandic Nature Conservation Act, 44, Section 1, 1999) wilderness characterizes approximately $33 \%$ of the total area of the country (Ólafsdóttir \& Runnstrom, 2011). Most of the wilderness areas are located in the Highlands and about $60 \%$ of the Highlands is wilderness (National Planning Agency, 2012).

The Central Highlands used to be a 'no man's-land' and its usefulness was limited to summer pasture for sheep. Since the end of the 1960s there has been considerable development in parts of the area. Hydro power plants have been built with good access roads, $4 \times 4$ tracks also cover a great deal of the area (Ministry of the environment \& The National Planning Agency, 1999). Despite that a qualitative study by Sæpórsdóttir (2010b) among Highland travelers shows that the most important components of the experience of the Highlands are unspoiled nature, beautiful and unique landscape, to experience freedom from a busy, hectic life, and not being in a crowded place.

\section{Methods and Data}

This research builds on questionnaire surveys, which have been gathered among travelers at nine areas in the southern Highlands in various research projects the author has conducted between 2007 and 2011. One of the areas is Landmannalaugar, the most visited destination in the Highlands. There are differences in accessibility between the areas as well as in the level of infrastructure (table 1). All the surveys focus on wilderness experience and most of the questions are the same so results from different areas can be compared. The study sites were purposively selected as being representative of the spectrum of nature tourist destinations in the Highlands, taking into account the level of development of infrastructure, the number of visitors, types of environment and difficulty of access.

Data collection was carried out at the main entrance point at each destination, either at parking places at the main attraction, or at mountain huts or on campsites. Data were collected by one or two interviewers who stayed at each destination for four days and up to a week during the peak tourist season in the summer. Ideally a random sample should have been taken dispersed evenly throughout the whole summer, but the financial resources of the studies did not allow that. Visitors were interviewed preferably after they had been in the area for a while and before they left the area, so that their experience/knowledge/opinion of the area was as great as possible. Those who were going to stay overnight in the area often took the questionnaire with them and answered it later, then the researcher came by later in the evening when the day traffic was over.

The questionnaires were available in English, German, French and Icelandic. Although this covered most requirements, it would have been beneficial to have Spanish and Italian versions as well. The questionnaires contained 32-39 questions, although not all of them were considered in the paper. The questions can be grouped into three categories:

1) Visitor characteristics. Includes age, gender, place of residence, party/group size, income and occupation (in some of the questionnaires).

2) Activities/behavior. Activities while in the area, length of stay, travel time, time spent on site, time spent hiking, travel mode, accommodation type, past visits and recreational use patterns.

3) Attitude/motivation. The area's attractiveness, attitudes towards natural and wilderness areas, appropriate facilities, opinion on number of visitors, satisfaction (with the biophysical condition, service and infrastructure). One of the questions was aimed explicitly at positioning the guests on the Purist Scale ('How important are the following facilities/characteristics for you while travelling in this area?').

Completed questionnaires were received from 3941 visitors with final response rate between $70 \%$ and $95 \%$, so the sample can be assumed to give a fair picture of the population with no serious bias.

The gender division is fairly equal in most places. The composition of nationality varies considerably between the research areas. Icelanders are about quarter of the total sample and up to one third in some of the areas. 
Germans and French are the most populous of the foreign visitors and other Western and Central Europeans also come in some numbers. In contrast North Americans are relatively few. The largest age groups are 25 to 34 and 45-54, counting for over twenty percent of the visitors (table 2).

Table 1. Research areas and data

\begin{tabular}{|c|c|c|c|c|c|c|}
\hline Research areas & $\mathrm{N}$ & $\begin{array}{l}\text { Year of } \\
\text { data } \\
\text { gathering }\end{array}$ & $\begin{array}{l}\text { Approximate } \\
\text { number of } \\
\text { travelers* }\end{array}$ & $\begin{array}{l}\text { Level of } \\
\text { tourism } \\
\text { development }\end{array}$ & Main tourist activity & Source for $(*)$ \\
\hline Álftavatn & 219 & 2011 & $6000-8000$ & Medium & $\begin{array}{l}\text { Mostly hiking. some } \\
\text { driving }\end{array}$ & $\begin{array}{l}\text { The Icelandic Travel } \\
\text { Association (2014) }\end{array}$ \\
\hline Eldgjá & 437 & 2011 & 20000 & Low & $\begin{array}{l}\text { Mostly driving. some } \\
\text { hiking }\end{array}$ & $\begin{array}{l}\text { Sæpórsdóttir and Ólafsson } \\
\text { (2012) }\end{array}$ \\
\hline Hrafntinnusker & 351 & 2011 & $6000-8000$ & Low & Hiking & $\begin{array}{l}\text { The Icelandic Travel } \\
\text { Association (2014) }\end{array}$ \\
\hline Hveravellir & 525 & 2008 & 21000 & High & $\begin{array}{l}\text { Mostly driving. some } \\
\text { hiking/riding }\end{array}$ & $\begin{array}{l}\text { Sæpórsdóttir and } \\
\text { Stefánsson (2009) }\end{array}$ \\
\hline Kerlingarfjöll & 128 & 2008 & 8500 & High & Mostly hiking & $\begin{array}{l}\text { Sæpórsdóttir and } \\
\text { Stefánsson (2009) }\end{array}$ \\
\hline Laki & 397 & 2007 & 8500 & Low & $\begin{array}{l}\text { Mostly driving, some } \\
\text { hiking }\end{array}$ & Ólafsson (2007) \\
\hline Landmannahellir & 180 & 2011 & unknown & Medium & Riding, driving, hiking & \\
\hline Landmannalaugar & 1646 & 2009 & 120000 & High & Hiking and driving & $\begin{array}{l}\text { Sæpórsdóttir and Ólafsson } \\
\text { (2012) }\end{array}$ \\
\hline Öldufell & 58 & 2011 & 8700 & Low & Driving and hiking & $\begin{array}{l}\text { Sæpórsdóttir and Ólafsson } \\
\text { (2012) }\end{array}$ \\
\hline Total & 3941 & & & & & \\
\hline
\end{tabular}




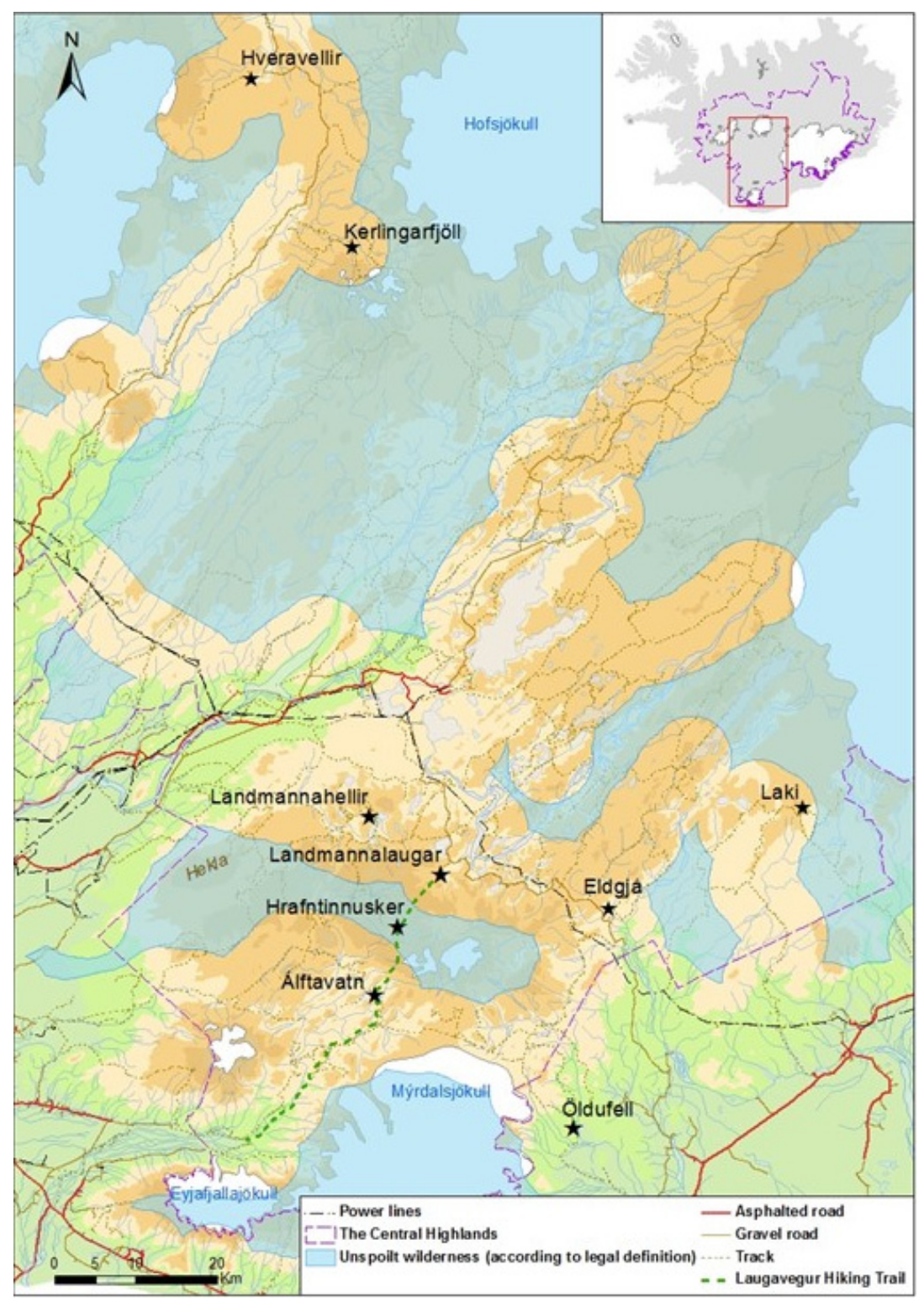

Figure 1. The research areas, legally defined wilderness and the Central Highlands

Table 2. Visitor characteristics

\begin{tabular}{llllllllll}
\hline Categories & $\begin{array}{l}\text { Álfta- } \\
\text { vatn }\end{array}$ & Eldgjá & $\begin{array}{l}\text { Hrafntinnu- } \\
\text { sker }\end{array}$ & $\begin{array}{l}\text { Hvera- } \\
\text { vellir }\end{array}$ & $\begin{array}{l}\text { Kerlingar- } \\
\text { fjöll }\end{array}$ & $\begin{array}{l}\text { Laki } \\
\text { hellir }\end{array}$ & $\begin{array}{l}\text { Landmanna- } \\
\text { laugar }\end{array}$ & Öldufell \\
\hline $\mathrm{N}$ & 219 & 437 & 351 & 525 & 128 & 397 & 180 & 1646 & 58 \\
Female & 47.5 & 51.5 & 46.8 & 49.0 & 53.1 & 49.1 & 56.7 & 49.0 & 43.1 \\
Male & 52.5 & 48.5 & 53.2 & 51.0 & 46.9 & 50.9 & 43.3 & 51.0 & 56.9 \\
Icelandic & 32.6 & 11.7 & 17.8 & 29.7 & 38.3 & 26.4 & 32.8 & 21.2 & 12.1 \\
German & 18.1 & 17.8 & 14.1 & 15.8 & 25.0 & 16.2 & 7.0 & 19.2 & 31.0 \\
French & 13.5 & 27.5 & 16.9 & 17.0 & 7.0 & 13.5 & 18.3 & 19.2 & 24.1 \\
Dutch/Belgian & 7.0 & 12.1 & 7.6 & 9.1 & 3.9 & 15.7 & 8.1 & 10.5 & 0.0 \\
Scandinavian & 6.0 & 1.4 & 11.0 & 11.0 & 9.4 & 2.0 & 9.1 & 7.9 & 6.9 \\
Swiss/Austrian & 4.2 & 12.1 & 5.4 & 4.0 & 10.9 & 8.6 & 11.3 & 5.9 & 6.9 \\
British & 8.8 & 2.3 & 10.7 & 1.9 & 0.0 & 2.0 & 0.5 & 5.8 & 0.0 \\
N. American & 0.9 & 3.9 & 3.7 & 0.6 & 0.0 & 1.5 & 0.5 & 5.7 & 1.7 \\
Spanish/Italian & 4.2 & 4.1 & 3.4 & 4.0 & 5.5 & 10.9 & 9.7 & 3.2 & 5.2 \\
\hline
\end{tabular}




\begin{tabular}{|c|c|c|c|c|c|c|c|c|c|}
\hline Other nations & 4.7 & 7.1 & 9.3 & 6.9 & 0.0 & 3.0 & 2.7 & 1.3 & 12.1 \\
\hline $24 \leq$ years & 15.8 & 11.1 & 20.9 & 7.1 & 12.6 & 8.9 & 11.2 & 14.0 & 19.0 \\
\hline $25-34$ yrs. & 36.4 & 20.3 & 36.8 & 19.2 & 14.2 & 16.5 & 16.2 & 30.3 & 20.7 \\
\hline $35-44$ yrs. & 15.3 & 18.7 & 18.2 & 22.3 & 20.5 & 21.4 & 17.9 & 18.2 & 10.3 \\
\hline 45-54 yrs. & 19.6 & 22.2 & 13.5 & 20.4 & 32.3 & 28.8 & 31.3 & 16.5 & 19.0 \\
\hline $55-64$ yrs. & 10.0 & 18.2 & 7.6 & 20.0 & 18.1 & 18.3 & 18.4 & 14.1 & 19.0 \\
\hline $65 \geq$ years & 2.9 & 9.5 & 2.9 & 11.0 & 2.4 & 6.1 & 5.0 & 6.8 & 12.1 \\
\hline
\end{tabular}

\section{Results}

\subsection{Appropriate Infrastructure}

The respondents were asked about the desirability of various facilities in the area they were travelling in. The results were marked on a five-point Likert scale $(1=$ very much against; $5=$ very much for) (figure 2$)$. Travelers in the Highlands are against most kinds of infrastructure. Opposition is strongest to power plants (average for all study sites 1.79). The respondents are also against hotels (2.17), gas stations (2.23) and restaurants (2.25). Travelers are more neutral towards built up gravel roads (2.68) and bridges for motorized vehicles (2.75).

Location in the Highlands and opinion of tourists there regarding what kind of human activities may be present in the area depend on one another $(p<0.000)$. In one location, Landmannalaugar the results differ highly from the results in the other eight research areas. Regarding every kind of infrastructure the difference is significant $(p<0.000)$ when Landmannalaugar is compared pairwise with each of the other areas. Visitors in Landmannalaugar are slightly positive towards gas stations (3.10), restaurants (3.23) and built up gravel roads (3.52) and mostly neutral towards hotels in the area (average for all study sites 2.97). They do though agree with the respondents in other areas that power plants are not desirable, although their opposition is not as strong as elsewhere.

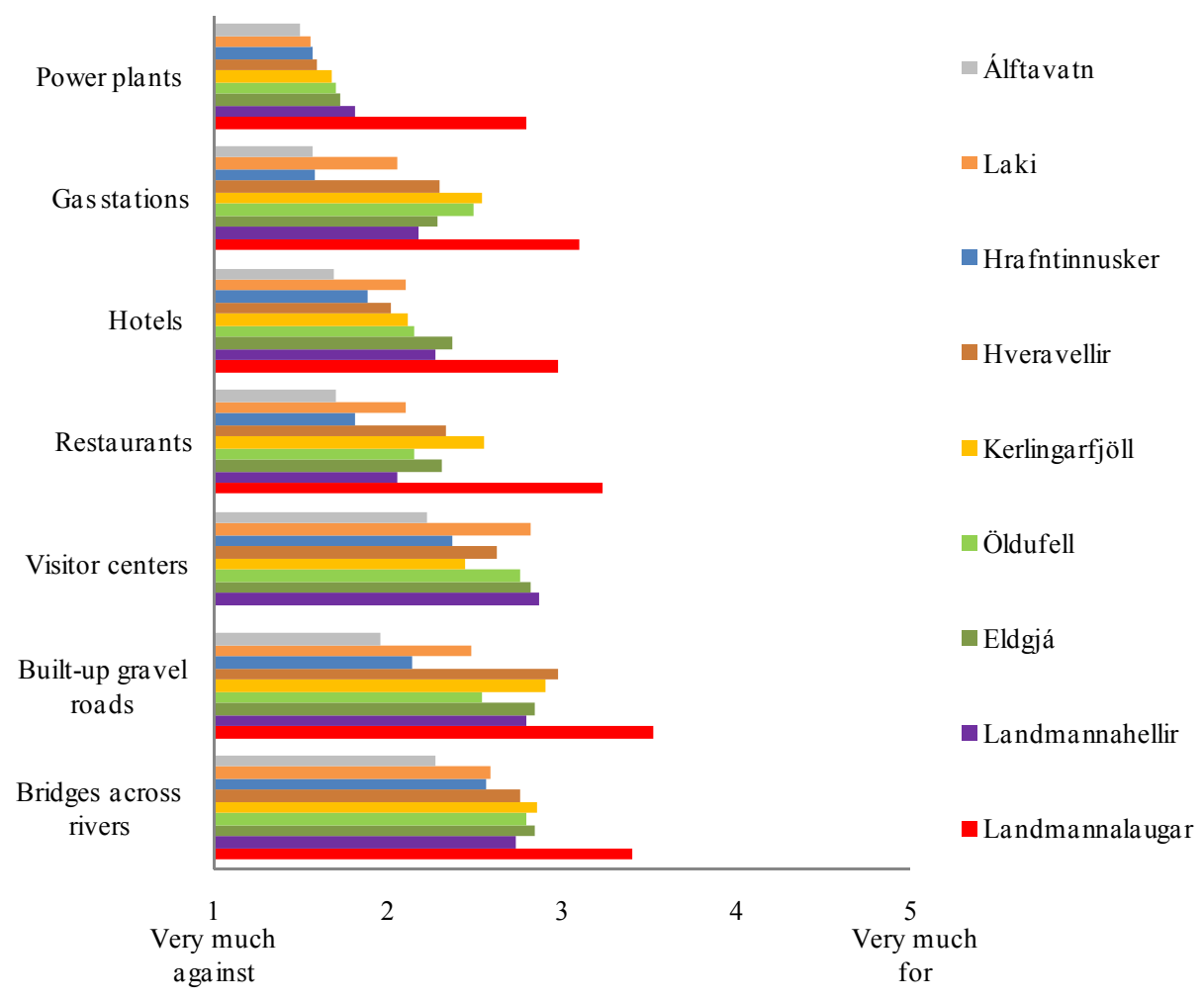

Figure 2. Your opinion about the following structures/facilities in the area 


\subsection{Perceived Wilderness}

In the minds of almost all tourists, or 96.6-99.4\% the Highland destination they visited is unspoiled wilderness (table 3) and the response to the statement "I think wilderness is a part of the appeal of the area" is statistically independent of location in the Highlands.

Table 3. Wilderness is a part of the attraction of the area (\%)

\begin{tabular}{ll}
\hline & Yes (\%) \\
\hline Álftavatn & 98.0 \\
Eldgjá & 97.4 \\
Hrafntinnusker & 99.4 \\
Hveravellir & 97.3 \\
Kerlingarfjöll & 98.2 \\
Laki & 97.7 \\
Landmannahellir & 98.2 \\
Landmannalaugar & 96.6 \\
Öldufell & 95.9 \\
\hline Average & 97.588 \\
SD & 1.0683 \\
\hline Pearson Chi-Square & 9.43 \\
df & 8 \\
Sig (2 sided) & 0.307 \\
\hline
\end{tabular}

\subsection{Visitors Opinion on Appropriate Number of Visitors}

The majority of visitors in the Highlands consider the number of tourists at the various research sites appropriate, on the average $73 \%$ (table 4 ). There are though a few warning signs as in three areas respondents considered that there are too many tourists in the area: In Landamannalaugar about one third, in Hrafntinnusker about $40 \%$ and at Álftavatn $26 \%$. There is a significant difference $(\mathrm{p}=0.000)$ whether the respondents at the various locations consider the number of tourists to be appropriate. The variation among the respondents is highest in Hrafntinnusker ( $\mathrm{SD}=1.008)$ but lowest in Kerlingarfjöll $(\mathrm{SD}=0.580)$.

Table 4. Attitudes towards the number of visitors

\begin{tabular}{llllll}
\hline & Too few (\%) & Suitable (\%) & Too many (\%) & Mean & SD \\
\hline Álftavatn & 4.8 & 68.8 & 26.4 & 3.48 & 0.937 \\
Eldgjá & 4.3 & 77.2 & 18.5 & 3.33 & 0.823 \\
Hrafntinnusker & 2.0 & 57.9 & 40.1 & 3.78 & 1.008 \\
Hveravellir & 4.1 & 87.0 & 8.8 & 3.13 & 0.614 \\
Kerlingarfjöll & 3.5 & 88.7 & 7.8 & 3.12 & 0.580 \\
Laki & 9.6 & 80.9 & 9.6 & 3.10 & 0.686 \\
Landmannahellir & 3.0 & 76.8 & 20.2 & 3.38 & 0.838 \\
Landmannalaugar & 2.6 & 65.5 & 31.8 & 3.61 & 0.963 \\
Öldufell & 7.4 & 75.9 & 16.7 & 3.26 & 0.828 \\
\hline Average & 4.2 & 73.1 & 22.7 & 3.35 & 0.809 \\
\hline
\end{tabular}

Note. Mean and SD are from a five-point Likert scale where $1=$ too few, $3=$ adequate, $5=$ too many.

\subsection{Environmental Damage}

Travelers in the Highland destinations do not notice much environmental damage but there is a significant difference $(\mathrm{p}=0.000)$ between what kind of damage the respondents at the various locations notice (table 5). Marks after off-road driving are most noticed, especially at Eldgjá, but least at Álftavatn. Erosion from hikers is the second most common environmental problem experienced by visitors, especially at Álftavatn. Damage to vegetation is mostly experienced at Laki and trampling by horses at Landmannahellir, garbage at Hveravellir and damage to geological formations at Kerlingarfjöll. 
Table 5. The Environmental damage visitors notice

\begin{tabular}{|c|c|c|c|c|c|c|c|c|c|c|c|c|}
\hline & \multicolumn{2}{|c|}{$\begin{array}{l}\text { Damage to } \\
\text { geological } \\
\text { formations }\end{array}$} & \multicolumn{2}{|c|}{ Garbage } & \multicolumn{2}{|c|}{$\begin{array}{l}\text { Trampling by } \\
\text { horses }\end{array}$} & \multicolumn{2}{|c|}{$\begin{array}{l}\text { Damaged } \\
\text { vegetation }\end{array}$} & \multicolumn{2}{|c|}{$\begin{array}{l}\text { Erosion of } \\
\text { foot paths }\end{array}$} & \multicolumn{2}{|c|}{$\begin{array}{l}\text { Traces of } \\
\text { off-road } \\
\text { driving }\end{array}$} \\
\hline & Mean & SD & Mean & SD & Mean & SD & Mean & SD & Mean & SD & Mean & SD \\
\hline Laki & 1.54 & 0.804 & 1.55 & 0.777 & NA & NA & 1.97 & 1.009 & 2.13 & 0.997 & 2.19 & 1.087 \\
\hline Hveravellir & 1.52 & 0.824 & 1.72 & 0.824 & 1.63 & 0.973 & 1.76 & 0.962 & 1.79 & 0.962 & 2.23 & 1.070 \\
\hline Kerlingarfjöll & 1.63 & 0.930 & 1.68 & 0.700 & 1.93 & 1.100 & 1.89 & 0.900 & 1.95 & 0.920 & 2.17 & 1.100 \\
\hline Eldgjá & 1.45 & 0.747 & 1.52 & 0.709 & 1.65 & 0.936 & 1.86 & 1.007 & 2.00 & 0.961 & 2.44 & 1.190 \\
\hline Hrafntinnusker & 1.35 & 0.632 & 1.56 & 0.723 & 1.41 & 0.803 & 1.76 & 0.985 & 2.35 & 1.133 & 1.92 & 1.015 \\
\hline Landmannahellir & 1.38 & 0.723 & 1.55 & 0.695 & 2.16 & 1.335 & 1.52 & 0.790 & 1.70 & 1.024 & 2.13 & 1.012 \\
\hline Álftavatn & 1.32 & 0.558 & 1.64 & 0.703 & 1.41 & 0.684 & 1.86 & 0.956 & 2.45 & 1.003 & 1.84 & 0.970 \\
\hline Öldufell & 1.29 & 0.497 & 1.44 & 0.660 & 1.73 & 0.891 & 1.78 & 0.917 & 1.87 & 1.048 & 2.36 & 0.923 \\
\hline Total & 1.43 & 0.715 & 1.58 & 0.724 & 1.70 & 0.960 & 1.80 & 0.941 & 2.03 & 1.006 & 2.16 & 1.046 \\
\hline $\mathrm{CV}$ & 2.01 & & 2.18 & & 1.77 & & 1.91 & & 2.02 & & 2.06 & \\
\hline
\end{tabular}

Note. Built on average on the 5 point Likert-scale where $1=$ not at all $\leftrightarrow 5=$ very much.

\subsection{Analyses of Visitors according to the Purist Scale}

Analyses of visitors attitudes according to Stankey's(1973) Purist Scale shows that there is a statistically significant difference between the average score in the eight areas (anova test $\mathrm{F}=5.515, \mathrm{p}=0.000$ ). The average score in Öldufell is different from the average score in all other areas $(p=0.000-0.022)$ and there is a significant difference between Laki and Hrafntinnusker $(p=0.003)$ (table 6).

Table 6. Scores according to the Purist Scale

\begin{tabular}{llllll}
\hline & Mean & SD & Min & Max & N \\
\hline Öldufell & 49.49 & 6.727 & 39 & 66 & 47 \\
Hrafntinnusker & 45.75 & 6.732 & 21 & 63 & 320 \\
Landmannahellir & 45.54 & 7.568 & 27 & 66 & 160 \\
Álftavatn & 45.34 & 7.394 & 27 & 63 & 183 \\
Hveravellir & 44.86 & 7.038 & 25 & 70 & 353 \\
Kerlingarfjöll & 44.86 & 8.325 & 25 & 65 & 106 \\
Landmannalaugar & 44.57 & 6.841 & 27 & 68 & 618 \\
Eldgjá & 44.11 & 6.971 & 26 & 68 & 368 \\
Laki & 43.58 & 6.586 & 23 & 63 & 317 \\
\hline & 45.34 & 0.550 & 21 & 70 & 2472 \\
\hline
\end{tabular}

The division of tourists according to the Purist Scale between the destinations is significantly different $(\chi 2=$ $75.23, \mathrm{p}=0.000, \mathrm{df}=24$ ) (figure 3). About half the respondents in all the areas are neutralists. Strong purists are very few, but their proportion is higher than expected from the chi-square test, in Öldufell $(9 \%)$ and Landmannahellir $(6 \%)$. Öldufell also has more purists $(36 \%)$ than expected from the chi-square test. The same applies to Hrafntinnusker (27\%). This confirms that tourists with strong puristic attitude are mostly to be found in the least developed, least accessible and least known tourist destinations in the Highlands, that is Öldufell and Hrafntinnusker. In the other destinations the proportion of purist-urbanist is very alike: Very few strong purists, about quarter purists, about half neutralists and about quarter urbanists. 


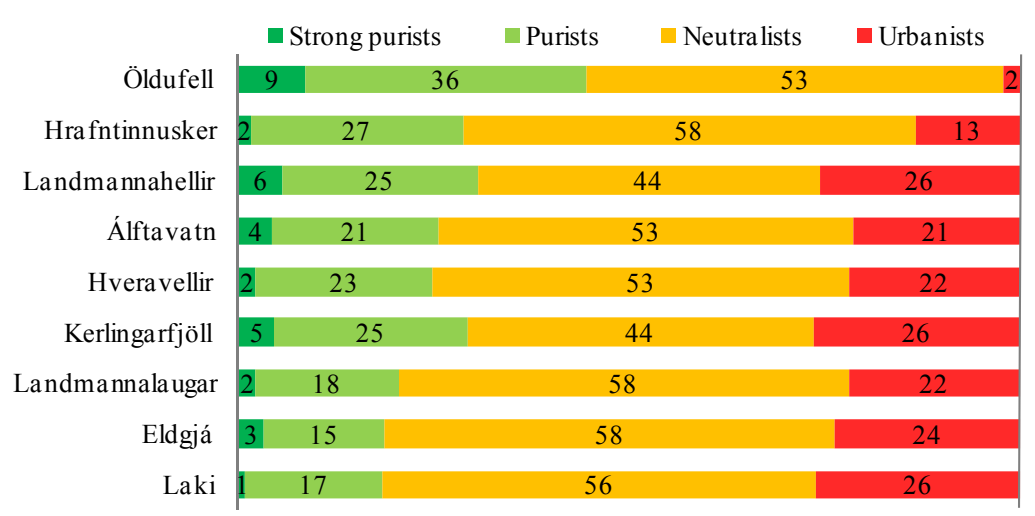

Figure 3. Division of tourists according to the Purist Scale

\section{Discussion}

Even though wilderness is more of an idea than a 'real' condition and should not be viewed from its etymological origins (Cronon, 1998; Demeritt, 2002; Pickerill, 2008; D. R. Williams, 2002; R. Williams, 1980) their existence in the minds of tourists in Iceland plays an important role for the tourism industry and the whole economy of Iceland. Despite the dramatic growth in the number of tourists to Iceland (Icelandic Tourist Board, 2013 ) the results of this study show that the majority $(73 \%)$ of visitors consider the number of tourists in the various Highland destinations appropriate. If the criteria made by Shelby and Heberlein (1986) is used, that the capacity of an area has been exceeded if more than two-thirds of the visitors experience crowding, the capacity of the Highlands of Iceland has not been reached. There are though some serious warning signs as in a few of the areas tourists consider tourists to be too many. One of them is Landmannalaugar where about one third considers there are too many tourists in the area. Perceived crowding can cause some tourists to change their travel pattern, e.g. go to less crowded areas (Kuss, Graefe, \& Vaske, 1990). This seems to be the case in Landmannalaugar which Highland visitors most frequently mention as a place not to visit anymore due to the high number of visitors (Sæpórsdóttir, 2012). According to a longitudinal study carried out in Landmannalaugar there has been a $50 \%$ increase in those who consider that there are too many tourists in the area, from $20 \%$ in the year 2000 , to $30 \%$ in 2009 (Sæpórsdóttir, 2013). If the fast growth in the number of tourists to Iceland continues this percentage can be expected to increase even further and it raises concerns whether Iceland as an emerging tourist destination will manage to preserve the wilderness.

This study shows that the travelers in the Highlands of Iceland prefer simplicity and the absence of technological human construction and they wish to keep the places as natural as possible. Hotels and restaurants are for example not seen as acceptable in the Highlands. This is in line with results from other studies (Hallikainen, 2000; Johnson, Hall, \& Cole, 2005; Manning, 1999; Sæbórsdóttir, 2010b; Vistad \& Vorkinn, 2012) that show that even constructions directly related to tourism and outdoor recreation reduce wilderness experience considerably. Attitudes among visitors at Landmannalaugar are though very different from the attitudes of visitors at other Highland destinations as they are more anthropocentric, favoring more humanized landscape and service. Results from Sæbórsdóttir (2013) show that considerable changes have occurred in the attitudes of visitors in Landmannalaugar in a decade and they have become more anthropocentric. The area is increasingly visited by tourists that consider that structures are acceptable in the area.

At the same time the study indicates that Landmannalaugar is perceived as wilderness by $97 \%$ of the visitors. This relates to the social construction of the wilderness idea where it has been pointed out that 'nature' and 'wilderness' is a cultural and historical construction developed in a social context (Cronon, 1998). Tuan (1990, p.112) has furthermore pointed out that "Wilderness" cannot be defined objectively: it is as much a state of the mind as a description of nature'. In this subjective sense, wilderness does not exist without an observer who experiences it and wilderness experiences are conceptualized through human feelings and relations shaped by extensive cultural and socio-historical processes.

There is an indication that Landmannalaugar has developed along Butler's (1980) life cycle and the type of travelers has changed. Purists have been displaced by neutralists and ubanists who experience wilderness despite the hundred thousand visitors there. The purists who used to visit the area would probably not experience Landmannalaugar today as a wilderness destination. Those purists have now been displaced by neutralists and 
urbanists who perceive the developed area as wild. That is travelers that make high demands on the quality of nature have started to avoid Landmannalaugar and visit now less touristic areas in the Highlands. They have been replaced by tourists with not as strict demands on wilderness qualities.

From the perspective of the social construction of wilderness one might not have to worry about the development of tourism in wilderness, as a new market group will replace those whose threshold is exceeded. The new market group will tolerate higher number of visitors and more humanized landscape and still perceive wilderness. That might be an acceptable solution if wilderness were purely a tourism product, waiting for the tourist industry to utilize it, but as wilderness is a finite tourism resource it would finally be overused, referring to Butler's TALC (1980). Not to mention the ethical obligation of humans to preserve nature and not let utilitarian perspective be dominant in all land use.

The Laugavegur hiking trail (figure 1) is the most popular long distance hiking trail in Iceland. In addition to Landmannalaugar, the starting or end point of the hiking trail, two other destinations along the route were studied in this research, Hrafntinnusker and Álftavatn. While about 100 thousand travelers visit Landmannalaugar approximately 6-8 thousand hikers pass through Hrafntinnusker and Álftavatn each summer (The Iceland Touring Association, 2013). Hikers coming to Laugavegurinn in the Highlands of Iceland probably do not expect as many hikers as there are. According to this study about one third of the respondents in Landmannalaugar, about $40 \%$ in Hrafntinnusker and $26 \%$ at Álftavatn considered that there are too many tourists in the area. Hrafntinnusker is the only research area located in pristine wilderness according to the legal definition (figure 1). The expectations of travelers towards experiencing solitude in an area of such a high environmental quality are probably not met when they after a day's hike in the wild, have to spend the night in a crowded campsite or mountain hut. Shelby and Heberlein (1986) emphasize the importance of expectations matching the reality tourists meet at a destination. These results indicate that hikers might be less tolerant towards crowding than other travelers. This is in line with what Santana and Hernández (2011) have pointed out, that tourist's perception of crowding depends on the activity they engage in. Shelby and Heberlein (1986) have emphasized the importance of distinguishing between the type of activity tourists engage in when determining TCC.

This research furthermore indicates that whether visitors consider the number of tourists appropriate or not does not depend on the actual number of tourists visiting the area. At Öldufell and Eldgja about the same proportion complain about overcrowding, $17 \%$ and 19\% respectively. At Öldufell very few travel, on the average 17 cars per day during the high summer season, while at Eldgjá the average is 232 cars per day (Sæbórsdóttir \& Ólafsson, 2012).

Even though the respondents to quite some extent perceive crowding, that feeling is not caused by them observing environmental damage as according to this study they only to a limited extent noticed environmental damage due to tourism. This is remarkable as research by Gísladóttir (2005) and Ólafsdóttir (2007) has shown that erosion of hike paths is a significant problem at some of the tourist destinations in the Highlands.

\section{Conclusions}

The more popular the Highland areas get, the more likely it is that the composition of guests will change (Sæbórsdóttir, 2007, 2010a). Increased numbers of visitors will drive away those who are most sensitive to crowding and more visitors require more infrastructure. A new market group will make more demands on goods and services. Knowing the perceptions of tourists and their threshold is therefore vital. If their threshold is exceeded they will move to other less touristic and less crowded destinations and the destination will start to decline. If the aim is to keep the current market group of visitors in the Highlands one should not invest in undesired infrastructure like hotels or restaurants, but try to keep the present image of wilderness. To avoid decline both crowding and the building of infrastructure must be managed according to goals set for the area, as is an important part of sustainable development (Jin \& Pearce, 2011).

The Icelandic governmental policy on sustainable development aims at preserving the wilderness (The ministry of the environment, 2010, 2011) and thereby limits must be recognized (Butler, 2004b, 2010; Saarinen, 2006). Using wilderness in a sustainable way as a tourism product is a very challenging task and requires great caution in an emerging destination where tourism growth is as fast as it is in Iceland.

\section{Acknowledgments}

This project would not have been possible without the financial support from the Minstry of Industries and Innovation, The Icelandic Tourist Board and The Icelandic Road Administration. I furthermore thank Ólöf Ýrr Atladóttir, director general at The Icelandic Tourist Board. Several students assisted me in different ways during 
the fieldwork and data processing: Anna Mjöll Guðmundsdóttir, Birgitta Stefánsdóttir, Helena Árnadóttir, Hjalti Nielsen, and borkell Stefánsson. Thank you all. I thank Ása Margrét Einarsdóttir for map making and Rögnvaldur Ólafsson the chairman of the board of the Icelandic Tourism Research Centre for helpful comments on the manuscript.

\section{References}

Butler, R. W. (1980). The concept of a tourism area cycle of evolution: Implications for management of resources. Canadian Geographer, 24(1), 5-12. http://dx.doi.org/10.1111/j.1541-0064.1980.tb00970.x

Butler, R. W. (1997). The concept of carrying capacity for tourism destinations: Dead or merely buried? In C. Cooper \& S. Wanhill (Eds.), Tourism development-Environmental and community issues (pp. 11-21). Chichester: John Wiley \& Sons.

Butler, R. W. (1999). Sustainable tourism: a state-of-the-art review. Tourism Geographies, 1(1), 7-25. http://dx.doi.org/10.1080/14616689908721291

Butler, R. W. (2004a). Geographical research on tourism, recreation and leisure: Origins, eras and directions. Tourism Geographies, 6(2), 143. http://dx.doi.org/10.1080/1461668042000208453

Butler, R. W. (2004b). Tourism, environment, and sustainable development. Environmental Conservation, 18(3), 201-209. http://dx.doi.org/10.1017/S0376892900022104

Butler, R. W. (2009). Tourism in the future: Cycles, waves or wheels? Futures, 41(6), 346-352. http://dx.doi.org/10.1016/j.futures.2008.11.002

Butler, R. W. (2010). Carrying capacity in tourism. In D. P. Pearce \& R. W. Butler (Eds.), Tourism Research. A 20-20 vision (pp. 53-64). Oxford: Goodfellow Publishers Limited.

Butler, R. W., Fennell, D. A., \& Boyd, S. W. (1992). The POLAR model: A system for managing the recreational capacity of Canadian heritage rivers. Ottawa: Environment Canada.

Cole, D. N. (2004). Carrying capacity and visitor management: Facts, values, and the role of science. Paper presented at the Protecting Our Diverse Heritage: The Role of Parks, Protected Areas, and Cultural Sites. (Proceedings of the 2003 George Wright Society / National Park Service Joint Conference), Hancock, Michigan.

Cronon, W. (1998). The trouble with wilderness; or, getting back to the wrong nature. In W. Cronon (Ed.), Uncommon ground: Rethinking the human place in nature (pp. 69-90). New York: W. W. Norton \& Co.

Demeritt, D. (2002). What is the 'social construction of nature'? A typology and sympathetic critique. Progress in Human Geography, 26(6), 767-790. http://dx.doi.org/10.1191/0309132502ph402oa

Fodor's Travel. (2012). from http://www.fodors.com/world/europe/iceland/

Fredman, P., \& Emmelin, L. (2001). Wilderness purism, willingness to pay and management preferences: A study of Swedish mountain tourists. Tourism Economics, 7, 5-20. http://dx.doi.org/10.5367/000000001101297702

Gísladóttir, G. (2005). The impact of tourist trampling on Icelandic andosols. Zeitschrift für Geomorphologie (Suppl.), 143, 55-73.

Hall, C. M., \& Saarinen, J. (2010). Polar tourism: Definitions and dimensions. Scandinavian Journal of Hospitality and Tourism, 10(4), 1-13. http://dx.doi.org/10.1080/15022250.2010.521686

Hallikainen, V. (2000). The Finnish "social wilderness" (Vol. RMRS-P-15-VOL-2): USDA Forest Service Proceedings.

Hammitt, W. E., \& Cole, D. N. (1987). Ecology and management. New York: Wiley.

Hendee, J. C., Catton Jr., W. R., Marlow, L. D., \& Brockman, C. F. (1968). Wilderness users in the Pacific Northwest: Their characteristics, values, and management preferences. Research paper $P N W$; (pp. iii, 92 p.). Portland, Oregon: Pacific Northwest Forest and Range Experiment Station.

Hendee, J. C., Stankey, G. H., \& Lucas, R. C. (1990). Wilderness management (2nd ed.). Golden, Colorado: North American Press.

Higham, J. E. S. (1998). Sustaining Wilderness in New Zealand in the Third Millennium: Wilderness policy developments and the increasing pressures of international tourist demand for wilderness in New Zealand. The High Latitudes Symposium, University of Surrey, UK 16 and 17 June, 1998. Retrieved June 29th, 2011, 
from http://divcom.otago.ac.nz/tourism/research/electronicpubs/sustainingwilderness/

Hunter, C., \& Green, H. (1995). Tourism and the environment: a sustainable relationship? Routledge.

Icelandic Nature Conservation Act, 44, Section 1 (1999).

Icelandic Tourist Board. (2012). International visitors in Iceland: Visitor survey summer 2011. Reykjavík: Icelandic Tourist Board.

Icelandic Tourist Board. (2013). Heildarfjöldi erlendra gesta 1949-2013 [The total number of foreign guests 1949-2013] Retrieved September 26th, 2013, from http://www.ferdamalastofa.is/is/tolur-og-utgafur/fjoldi-ferdamanna

Icelandic Tourist Board. (2014). Heildarfjöldi erlendra gesta 1949-2014 [The total number of foreign guests 1949-2014] Retrieved January 16th, 2014, from http://www.ferdamalastofa.is/is/tolur-og-utgafur/fjoldi-ferdamanna

Jin, Q., \& Pearce, P. (2011). Tourist perception of crowding and management approaches at tourism sites in Xi'an. Asia Pacific Journal of Tourism Research, 16(3), 325-338. http://dx.doi.org/10.1080/10941665.2011.572667

Johnson, B. J., Hall, T. E., \& Cole, D. N. (2005). Naturalness, primitiveness, remoteness and wilderness: Wilderness visitors' understanding and experience of wilderness qualities. Retrieved December 15th, 2010, from http://leopold.wilderness.net/unpublished/UNP115.pdf

Kuss, F. R., Graefe, A. R., \& Vaske, J. J. (1990). Visitor impact management. A review of research (Vol. 1). Washington, D.C.: National Parks and Conservation Association.

Lawson, S., \& Manning, R. (2001). Solitude versus access: A study of tradeoffs in outdoor recreation using indifference curve analysis. Leisure Sciences, 23(3), 179-191. http://dx.doi.org/10.1080/014904001316896864

Lime, D., \& Stankey, G. H. (1971). Carrying capacity: Maintaining outdoor recreation quality. Paper presented at the Recreation Symposium, Upper Darby, PA.

Manning, R. E. (1999). Studies in outdoor recreation: Search and research for satisfaction (2nd ed.). Corvallis, OR: Oregon State University Press.

Manning, R. E., Valliere, W. A., \& Wang, B. (1999). Crowding norms: Alternative measurement approaches. Leisure Sciences, 21(2), 219-229. http://dx.doi.org/10.1080/014904099273174

McCool, S. F., Clark, R., \& Stankey, G. H. (2007). An assessment of frameworks useful for public land recreation planning. Portland, OR: U.S. Department of Agriculture, Forest Service, Pacific Northwest Research Station.

Ministry of the environment, \& The National Planning Agency. (1999). Miðhálendi Íslands, Svceðisskipulag 2015 [The Central Highlands, regional planning 2015]. Reykjavík: Umhverfisráðuneytið and Skipulagstofnun.

Nash, R. (2001). Wilderness and the American mind (4th ed.). New Haven; London: Yale University Press.

National Planning Agency. (2012). Environmental report with updated proposal for national planning strategy and responses to comments [Umhverfisskýrsla með uppfcerðri tillögu að landsskipulagsstefnu og viðbrögðum við athugasemdum]. Reykjavík: National Planning Agency. Retrieved from http://www.landsskipulag.is/media/landsskipulagsstefna/Umhverfisskyrsla_landsskipulagsstefnu_med-uppf aerdr.pdf.

Ólafsdóttir, R. (2007). The Physical carrying capasity og Laki. In A. D. Sæpórsdóttir (Ed.), Tourism carrying capasity at Laki [Ferðamennska við Laka]. Höfn: Háskólasetrið á Hornafirði.

Ólafsdóttir, R., \& Runnstrom, M. C. (2011). How wild is Iceland? Assessing wilderness quality with respect to nature based tourism. Tourism Geographies, 13(2), 280-298. http://dx.doi.org/10.1080/14616688.2010.531043

Patterson, M., \& Hammitt, W. (1990). Backcountry encounter norms, actual reported encounters, and their relationship to wilderness solitude. Journal of Leisure Research, 22(3), 259-275.

Pickerill, J. (2008). From wilderness to wild country: The power of language in environmental campaigns in Australia. Environmental Politics, 17(1), 95-104. http://dx.doi.org/10.1080/09644010701811681 
Roggenbuck, J. W., Williams, D. R., \& Watson, A. E. (1993). Defining acceptable conditions in wilderness. Environmental Management, 17(2), 187-197. http://dx.doi.org/10.1007/BF02394689

Saarinen, J. (1998). Wilderness, tourism development, and sustainability: Wilderness attitudes and place ethics. Paper presented at the Personal, societal, and ecological values of wilderness: Sixth World Wilderness Congress proceedings on research, management, and allocation, volume I, Bangalore, India.

Saarinen, J. (2006). Traditions of sustainability in tourism research. Annals of Tourism Research, 33(4), 1121-1140. http://dx.doi.org/10.1016/j.annals.2006.06.007

Saarinen, J. (2013a). Critical Sustainability: Setting the Limits to Growth and Responsibility in Tourism. Sustainability, 6(1), 1-17. http://dx.doi.org/10.3390/su6010001

Saarinen, J. (2013b). 'Tourism into the wild': The limits of tourism in wilderness. In A. Holden \& D. A. Fennell (Eds.), The Routledge Handbook of Tourism and the Environment (pp. 145-154). London: Routledge.

Sæpórsdóttir, A. D. (2007). Planning Nature tourism using the Purist Scale. Paper presented at the the 14th Nordic Symposium in Tourism and Hospitality Research, Akureyri, Iceland.

Sæpórsdóttir, A. D. (2010a). Planning nature tourism in Iceland based on tourist attitudes. Tourism Geographies, 12(1), 25-52. http://dx.doi.org/10.1080/14616680903493639

Sæbórsdóttir, A. D. (2010b). Tourism struggling as the wilderness is developed. Scandinavian Journal of Hospitality and Tourism, 10(3), 334-357. http://dx.doi.org/10.1080/15022250.2010.495485

Sæpórsdóttir, A. D. (2012). Ferðamennska á miðhálendi Íslands: Staða og spá um framtíðarhorfur [Tourism in the Central-Highlands. Current situation and future expectations]. Reykjavík: Institute of Life and Environmental Sciences, University of Iceland.

Sæpórsdóttir, A. D. (2013). Managing popularity: Changes in tourist attitudes to a wilderness destination. Tourism Management Perspectives, 7, 47-58. http://dx.doi.org/10.1016/j.tmp.2013.04.005

Sæpórsdóttir, A. D., \& Ólafsson, R. (2012). Áhrif Hólmsárvirkjunar á ferðamennsku og útivist [The effect of the proposed power plant Hómsárvirkjun on tourism and recreation] (Vol. LV-2012-020). Reykjavík: Landsvirkjun og Orkusalan.

Santana, J. Y., \& Hernández, J. M. (2011). Estimating the effect of overcrowding on tourist attraction: The case of Canary islands. Tourism Management, 32(2), 415-425. http://dx.doi.org/10.1016/j.tourman.2010.03.013

Shelby, B., \& Heberlein, T. A. (1986). Carrying capacity in recreation settings. Corvallis: Oregon State University Press.

Simón, F. J. G., Narangajavana, Y., \& Marqués, D. P. (2004). Carrying capacity in the tourism industry: a case study of Hengistbury Head. Tourism Management, 25(2), 275-283. http://dx.doi.org/10.1016/S0261-5177(03)00089-X

Stankey, G. H. (1973). Visitor perception of wilderness recreation carrying capacity (Vol. USDA Forest Service Research Paper INT-142.). Ogden, Utah: Intermountain Forest \& Range Experiment Station, Forest Service, U.S. Dept. of Agriculture.

Statistics Iceland. (2014). External trade. Trade in goods and services. Trade in services. Major items of the exports of goods and services 2009-2013. Retrieved April 6th, 2014, from http://www.statice.is/pages/2272

The Iceland Touring Association. (2013). Easily passable hiking trails in more areas [Greiðar leiðir um fleiri svæði]. Morgunblaðið. Aukablað: Ferðumst saman., 17th. May, 13.

The ministry of the environment. (2010). Welfare for the future. Iceland's national strategy for sustainable development. Emphasis 2010-2013 [Velferð til framtiðar. Sjálfbar próun i íslensku samfélagi. Áherslur 2010-2013]. Reykjavík: The ministry of the environment.

The ministry of the environment. (2011). In Aagot V. Óskarsdóttir (Ed.), Hvitbók um löggjöf til verndar náttúru Íslands [White book on nature protection law in Iceland]. Reykjavík: The ministry of the environment.

Thórhallsdóttir, T. E. (1997). Tundra ecosystems in Iceland. In F. E. Wielgolaski (Ed.), Tundra ecosystems of the World (Vol. 3. Polar and Alpine Tundra, pp. 85-96). Amsterdam: Elservier.

Thórhallsdóttir, T. E. (2002). Evaluating nature and wilderness in Iceland. Paper presented at the Wilderness in the Circumpolar North: Searching for compatibility in ecological, traditional, and ecotourism values. , Anchorage, AK. 
Tuan, Y. F. (1990). Topophilia : A study of environmental perception, attitudes, and values (Morningside ed.). New York, NY: Columbia University Press.

UNWTO. (2014). World Tourism Barometer. Madrid: UNWTO. Retrieved from http://media.unwto.org/en/press-release/2013-01-28/international-tourism-continue-robust-growth-2013

Vistad, O. I., \& Vorkinn, M. (2012). The Wilderness Purism Construct-Experiences from Norway with a simplified version of the purism scale. Forest Policy and Economics, 19(0), 39-47. http://dx.doi.org/10.1016/j.forpol.2011.12.009

Williams, D. R. (2002, May 15-17, 2001). The social construction of arctic wilderness: Place meanings, value pluralism, and globalization. Paper presented at the Wilderness in the Circumpolar North: Searching for compatibility in ecological, traditional, and ecotourism, values, University of Alaska, Anchorage.

Williams, D. R., Roggenbuck, J. W., \& Bange, S. (1991). The effect of norm-encounter compatibility on crowding perceptions, experience, and behaviour in river recreation settings. Journal of Leisure Research, 23(2), 154-172.

Williams, P. W., \& Gill, A. (2004). Addressing carrying capacity issues in tourism destinations through growth management. In W. Theobald (Ed.), Global Tourism (pp. 194-212). London: Elsevier.

Williams, R. (1980). Ideas of nature. In R. Williams (Ed.), Problems of materialism and culture. London: Verso.

\section{Copyrights}

Copyright for this article is retained by the author(s), with first publication rights granted to the journal.

This is an open-access article distributed under the terms and conditions of the Creative Commons Attribution license (http://creativecommons.org/licenses/by/3.0/). 